\title{
KEBERLANJUTAN JURNALISTIK SEHAT DI ERA KONVERGENSI DARING SUARASURABAYA.NET DENGAN PENDEKATAN ENGAGEMENT PYRAMID
}

\section{Healthy Journalistic Sustainabilty in the Online Convergence Era of Suarasurabaya.net within Engagement Pyramid Approach}

\author{
Anak Agung Istri Prihandari Satvikadewi ${ }^{1)}$, Irmasanthi Danadharta ${ }^{2)}$ dan Bambang Aprianto ${ }^{3)}$ \\ 1) 2) 3) Ilmu Komunikasi, FISIP, Universitas 17 Agustus 1945 (UNTAG) Surabaya \\ 1) 2) 3) Jl. Semolowaru 45 Surabaya 60118
}

Diterima 20 Maret 2019 / Disetujui 20 September 2019

\begin{abstract}
The approach of engagement pyramid, which is a response to the increasingly complex relations between consumers and producers in the digital era, offers a solution so that the sustainability of an organization, product or a particular brand can be maintained, through one key concept: engagement. Applying the approach of the engagement pyramid in online journalism enables the creation of a healthy journalistic process, because the demands of high speed verification and curation procedure of the news or other journalistic products can still be fulfilled through the stages of engagement. The stages of engagement include watching, sharing, commenting, producing and curating. This article is a summary of research on the application of engagement pyramid in the news media portal http://suarasurabaya.net. With the case study method, Suara Surabaya dot Net was chosen as a subject based on meeting criteria as convergent media. As a result, the pyramid engagement approach has implications for the continuity of good relations between the media and listeners, which also have consequences on the structure of the writings as the product of online journalism, considering that media platform used (radio, portal, social media and micro blogging) each has specific characteristics.
\end{abstract}

Keywords: Engagement Pyramid, Healthy Journalistic, Online Convergence, Suarasurabaya.net.

\begin{abstract}
ABSTRAK
Pendekatan engagement pyramid yang merupakan respon terhadap semakin kompleksnya relasi antara produsen di era digital dan konsumen, menawarkan jalan tengah agar keberlanjutan sebuah organisasi, produk maupun brand dapat terjaga, melalui satu konsep kunci yaitu keterlibatan. Pendekatan piramida keterlibatan dalam jurnalisme daring memungkinkan terciptanya proses jurnalistik yang sehat, karena meskipun dalam tuntutan kecepatan yang tinggi, verifikasi dan kurasi berita atau produk jurnalistik lainnya tetap tetap bisa dilakukan melalui tahap-tahap keterlibatan. Tahap-tahap keterlibatan tersebut meliputi watching, sharing, commenting, producing dan currating. Artikel ini merupakan ringkasan dari penelitian tentang penerapan engagement pyramid di media portal berita http://suarasurabaya.net. Dengan metode studi kasus, Suara Surabaya dot Net dipilih sebagai subjek berdasarkan pemenuhan kriteria sebagai media konvergen. Hasilnya, pendekatan engagement pyramid selain berimplikasi pada keberlanjutan hubungan baik antara media dengan pendengar juga berkonsekuensi pada struktur penulisan produk jurnalistik, mengingat masing-masing platform media yang digunakan (radio, portal, media sosial dan micro blogging) memiliki karakteristik yang spesifik.
\end{abstract} Kata Kunci: Engagement Pyramid, Jurnalistik Sehat, Konvergensi Daring, Suarasurabaya.net.

\footnotetext{
*Korespondensi Penulis:

Email : vika@untag-sby.ac.id
} 


\section{PENDAHULUAN}

\section{Latar Belakang Masalah}

Perkembangan teknologi berbasis internet yang tak terbendung terus mendorong tumbuhnya industri media baru (new media). Terminologi 'media baru' sendiri merujuk pada konvergensi antara media konvensional dengan teknologi komunikasi digital yang terkomputerisasi serta terhubung ke dalam jaringan. Media baru memiliki 3 sifat utama yaitu integrasi, interaktif dan terdigitalisasi (digitalized).

Fenomena-fenomena yang terjadi pada dan melibatkan media baru kemudian dapat dipahami sebagai sebuah proses kultural yang merepresentasikan perubahan sosial sekaligus perubahan nilai-nilai dalam masyarakat di era ini, era yang dikenal sebagai era kapitalisme global. Masyarakat di era ini adalah masyarakat konsumen (consumer society), yaitu masyarakat hidup di tengah budaya industri. Dalam budaya industri, segala sesuatu diproduksi secara massal, tak terkecuali produk-produk jurnalistik. Kerja jurnalistik yang pada awalnya merupakan proses intelektual, bergeser menjadi sebuah proses kerja komersial (Permadi, 2019:24). Sebutan praproduksi, produksi, dan pemasaran dalam proses kerja jurnalistik di era kapitalisme global ini berkonotasi fisik-materil dan berkonteks ekonomi. Kerja jurnalisme yang berada dalam situasi industrial tentunya harus menyesuaikan diri dengan manajemen media yang menaunginya, selain juga harus menyesuaikan diri dengan tuntutan pasar yang menjadi khalayak sasarannya, yakni konsumen media, yang terdiri dari khalayak pembaca, pendengar, penonton dan pengakses internet (netizen/warganet). Sementara itu, pergeseran pola kepemilikan media yang cenderung semakin terkonsentrasi pada individu atau kelompok korporasi tertentu, juga berpengaruh pada tampilan dan isi produk-produk jurnalistik, mulai dari berita surat kabar, program news bulletin televisi, sampai headline media online di seluruh dunia nyaris telah menjadi mirip satu sama lain. Keberagaman informasi lenyap sebagai akibat dari meningkatnya konsentrasi kepemilikan media (Nugroho, Putri, \& Laksmi, 2012:50).

Tokoh pers nasional Ashadi Siregar, dalam sebuah orasi ilmiah di Surabaya (Winarni \& Lestari, 2019:87) pernah menyatakan, "Jurnalisme dapat "dimakan" oleh manajemen jika para wartawan tidak menempatkan secara proporsional entitas keredaksian sebagai sub-sistem dalam sistem keseluruhan. Tantangan profesionalisme wartawan di masa depan bukan hanya mengembangkan teknik jurnalisme pada tingkat bagaimana (how) untuk menformat realitas menjadi informasi, tetapi lebih jauh menempatkan output-nya dalam keseluruhan sistem manajemen penerbitan pers.

Dalam konteks produk jurnalistik, kekhawatiran bahwa 'jurnalisme dimakan oleh manajemen' itu sebenarnya sudah terlihat sangat nyata dalam perkembangan media sepuluh tahun terakhir ini. Maraknya penggunaan judul click bait adalah contoh bagaimana ancaman terhadap prinsipprinsip jurnalistik berlangsung. Judul berita click bait, meskipun dinilai oleh Aliansi Jurnalis Independen (AJI) cenderung memanipulasi pembaca, dari aspek komersial justru sangat menguntungkan.

Seseorang dapat tertipu oleh judul yang terkesan dramatik, namun saat dibaca lebih lanjut, isinya jauh berbeda dari judulnya. Judul berita click bait biasanya lebih panjang, lebih sensasional daripada judul-judul berita pada umumnya. Misalnya, judul berita: 'Inilah Bukti Mengapa Kamu Masih Jomblo, No. 5 Bisa Bikin Merinding!'.

Menurut Nasrullah (2014:39), perubahan performa jurnalistik merupakan implikasi dari kehadiran media siber (media berbasis internet). (Alatas \& Sutanto, 2019:167) mengatakan, pada dasarnya, media baru memiliki sifat serba sangat mudah: sangat mudah diproses (easily processed), sangat mudah disimpan (easily stored), sangat mudah diubah/ ditransformasikan (easily transformed), sangat mudah dipanggil ulang (easily retrieved), sangat mudah dicari (easily searched for) dan sangat mudah diakses (easily accessed). Semua keserba-mudahan itu merupakan konsekuensi logis dari sifat 
teknologi internet yang terlampauterhubung (hyper-linked).

Keserba-mudahan itu pula yang turut mengubah perilaku dan proses produksi, distribusi dan konsumsi produk jurnalisme online (Prilani, 2017:517). Meskipun kepemilikan media terkonsentrasi secara kapital, namun munculnya jurnalisme warga (citizen journalism) secara langsung maupun tidak langsung ikut memengaruhi agenda media. Pemilik media mungkin saja mengendalikan isi berita, namun kemudahan akses yang dimiliki oleh setiap warganet untuk mengunggah suatu topik atau isu tertentu, memungkinkan mereka untuk terlibat dalam proses mengkonstruksi, merekonstruksi bahkan mendekonstruksi agenda media.

Khalayak memiliki peluang dan potensi besar untuk menentukan arah media, dan karena mereka memiliki preferensi masing-masing, media atau organisasi berita merespons dengan menyelaraskan diri. Secara sengaja maupun tidak, media kemudian cenderung lebih dekat dengan salah satu kubu politik atau dengan salah satu kelompok partisan, khalayak menjadi semakin terpecah-pecah dan terpolarisasi. Ketika pembaca berita dipolitisasi secara terbuka, surat kabar dan jaringan media tidak punya pilihan selain berubah seiring waktu dengan mengorbankan kredibilitas mereka.

Masalah lain adalah fakta bahwa teknologi internet menjadikan sirkulasi berita makin cepat dan nonstop selama 24 jam. Hal ini menempatkan wartawan pada posisi sulit karena harus mengunggah laporan atau menyajikan berita tanpa pengecekan fakta. Di Amerika, Washington Post dan New York Times sampai-sampai terpaksa harus menarik kembali sejumlah berita politik yang telah mereka terbitkan karena pembaca mengeluhkan ketidakakuratan pada berita-berita tersebut.

Dari semua hal yang disebutkan di atas, semakin nyata kiranya, bahwa tantangan terbesar bagi jurnalis, reporter dan editor berita media daring (online journalism) adalah, bagaimana menyediakan liputan, berita dan produkproduk jurnalistik lainnya yang akurat secepat mungkin dengan semaksimal mungkin pula menghindari kesalahan maupun bias.

Salah satu media yang telah menerapkan terobosan jurnalisme daring adalah Suara Surabaya Media, dengan manajemen konvergensi medianya yang meliputi radio Suara Surabaya, majalah Surabaya City Guide, portal berita suarasurabaya.net, dan media sosial e-100 (Khadziq, 2016:15). Suara Surabaya menerapkan pendekatan engagement pyramid dalam kebijakan redaksional pada media berbasis internet yang dikelolanya, dalam hal ini portal berita suarasurabaya.net. Pendekatan engagement pyramid ini diformalkan melalui SOP, dengan dasar pemikiran memperhatikan keberbedaan karakteristik media, karakteristik khalayak, dan tentunya karakteristik pesan antara satu media dengan media lainnya. Dengan kata lain, sekalipun Suara Surabaya Media mengelola media-media dengan produk/konten utama berita, pada prakteknya karakteristik berita radio berbeda dengan berita majalah, berbeda dengan media online portal berita, berbeda pula dengan media sosial.

Engagement pyramid merupakan strategi yang diadaptasi dari best practice dalam manajemen organisasi yang dicetuskan oleh Charlene Li (Baughan, 2019:60). Engagement Pyramid mendeskripsikan secara visual bagaimana cara menciptakan engagement (keterlibatan) tentang berbagai cara terlibat dengan pelanggan, dalam konteks media, keterlibatan dengan pembaca, pendengar, atau penonton. Dimulai dengan mengakses, kemudian diikuti dengan berbagi, lalu berkomentar, memproduksi dan akhirnya kurasi (Baughan, 2019:61).

\section{Identifikasi Masalah}

Jurnalisme daring (online journalism) memerlukan terobosanterobosan baru yang bersifat praktis dan dapat langsung diterapkan (applicable). Pendekatan engangement pyramid dalam struktur naskah jurnalisme daring merupakan terobosan yang dilakukan di manajemen pemberitaan Suara Surabaya Media. Karena itu masalah dalam makalah 
ini akan dibatasi pada bagaimana bentukbentuk penerapan engagement pyramid pada struktur naskah berita yang diproduksi oleh portal berita http://suarasurabaya.net, portal berita di bawah pengelolaan Suara Surabaya Media. Pengamatan akan dilakukan pada naskah-naskah berita yang dimuat pada situs portal berita online http://suarasurabaya.net.

\section{Tujuan dan Manfaat Penelitian}

Penelitian ini bertujuan untuk mendeskripsikan bagaimana pendekatan bentuk-bentuk penerapan engagement pyramid pada struktur naskah berita yang diproduksi oleh portal berita http://suarasurabaya.net. Manfaat dari penelitian ini adalah untuk menambah khazanah dalam kajian jurnalisme, khususnya jurnalisme daring, dan membuka kemungkinan bagi pendekatan Engagement Pyramid diterapkan dalam praktik redaksional media, khususnya media baru yang berbasis internet.

\section{METODE PENELITIAN}

\section{Studi Kasus}

Penelitian ini merupakan penelitian jenis Studi Kasus. Studi Kasus merupakan metode yang ada dalam kelompok analisis kerja dan pengalaman individual serta perilaku institusi. Studi Kasus adalah salah satu strategi dan metode analisis kualitatif yang menekankan pada kasus-kasus khusus yang terjadi pada objek analisis. Dengan mengunakan payung paradigma fenomenologi, Studi Kasus memusatkan perhatian pada satu objek tertentu yang diangkat sebagai sebuah kasus untuk dikaji secara mendalam sehingga mampu membongkar realita di balik fenomena. Tugas peneliti studi kasus ialah menggali sesuatu yang tampak untuk menjadi pengetahuan yang tampak.

Dipilihnya http://suarasurabaya. net sebagai subjek kasus berdasarkan pertimbangan bahwa media protal berita ini merupakan aktualisasi konkrit dari konvergensi media (Hamna, 2018:70).
Diawali dari media induknya, Suara Surabaya sebagai radio lokal konvensional sangat unik, Suara Surabaya 100 FM telah menerapkan konsep format siaran radio (20\% musik dan $80 \%$ berita) News dan informasi yang interaktif sejak 1995. Dalam platform radio konvensional, Radio Suara Surabaya merupakan radio yang memelopori juranlisme warga (citizen journalism) dibuktikan dengan konsistensi dan banyaknya warga yang antusias mengirimkan laporan dan berita pada sosial media Suara Surabaya dari waktu ke waktu (Trinoviana, 2017:40).

\section{HASIL DAN PEMBAHASAN}

\section{Perwajahan Suara Surabaya dot Net}

Portal Berita Suara Surabaya dot Net (http://suarasurabaya.net) awalnya hanya berfungsi sebagai web untuk streaming siaran Radio Suara Surabaya. Pada tahun 1997, tampilannya hanya berisi link yang dapat diklik untuk mendengarkan radio melalui internet, belum ada berita dalam format tertulis maupun foto. Pada tahun 1999, tampilan website sudah mulai memiliki menu-menu utama, berisi transkrip dari siaran on air dan laporan reporter. Jika sebelumnya konten Suarasurabaya.net hanya apa yang diudarakan di radio, maka sejak ada kewajiban mencari berita sendiri untuk kepentingan portal, redaksi on air bisa justru sebaliknya bisa mengambil materi siaran dari website.

Pada tahun 2008, Suara Surabaya resmi mengembangkan konvergensi dengan video streaming, radio streaming, dan radio on demand. Tahun 2009 membuat fanpage E100 di Facebook, tahun 2010 tampil di @SSFM100 dan mobile broadcast di Blackberry, dan tahun 2012 mengembangkan mobile application di Android dan iOS (Asy'ari \& Luthfi, 2018:4). Konsep konvergensi "integrasi berita dari web, mobile, dan sosial media ke radio, begitu juga sebaliknya" diterapkan hingga sekarang. 


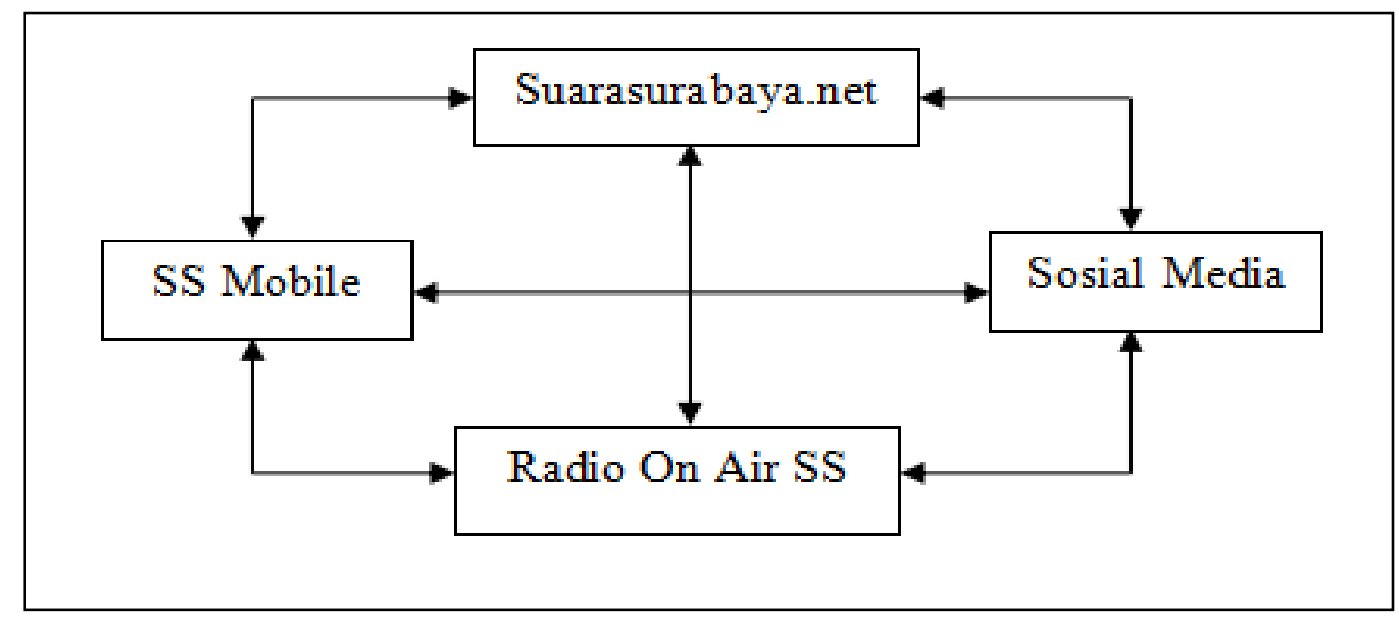

\section{Gambar 1. Konsep Konvergensi Suara Surabaya Media \\ Sumber: Wawancara manajemen suarasurabaya.net}

Apa yang dilakukan Suara Surabaya Media, sejalan dengan yang dikatakan (Sediyaningsih, 2018:55) bahwa konvergensi media merupakan proses penggabungan antara media, industri telekomunikasi dan komputasi, dan penyatuan segala bentuk komunikasi termediasi dalam bentuk digital. Secara konkrit semua media tersebut terintegrasi ke dalam satu portal http://suarasurabaya.net, namun secara fisik, masing-masing media juga tetap eksis dalam bentuk dan karakteristiknya masingmasing.

Gambar 2 menunjukkan bagaimana perbandingan tampilan beranda portal berita http://suarasurabaya.net dengan laman radio online di portal http://suara surabaya.net Menu-menu yang ditampilkan, merepresentasikan integrasi antara konten Radio Suara Surabaya dengan platform teknologi digital yang meliputi: radio streaming, video streaming, radio on demand. Di sisi lain, bentuk-bentuk program on air di Radio Suara Surabaya tampil dalam bentuk visual dan berubah dari bentuk lisan menjadi tulisan.

Jika di radio, penanda tingkat urgensi sebuah berita dan bentuk program lainnya adalah alokasi waktu dan durasi, maka dalam format media online, kontenkonten tersebut tampil dalam bentuk grafis dan penempatan posisi pada keseluruhan tata letak (lay out) perwajahan portal.
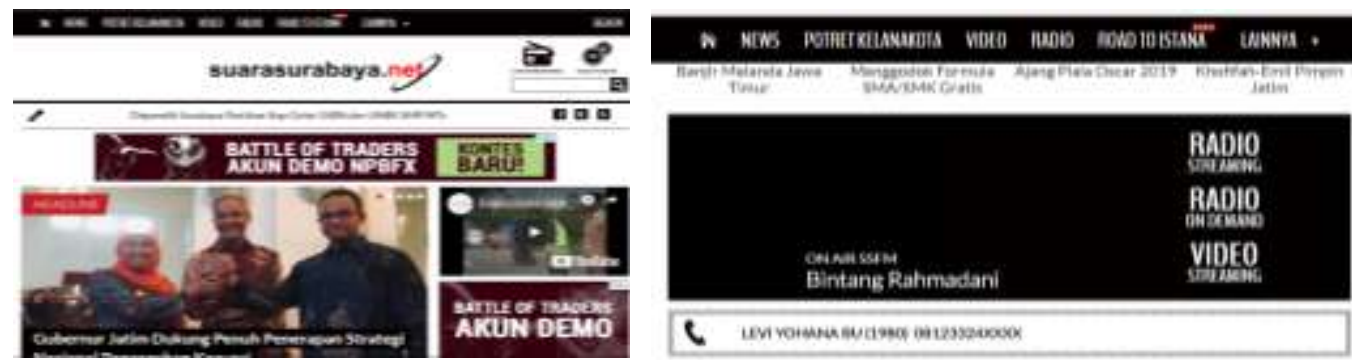

Gambar 2. Perbandingan Tampilan Beranda Portal Berita dan menu Radio Online Suara Surabaya pada http://suarasurabaya.net Sumber: http://suarasurabaya.net 
Selain dalam bentuk tulisan dan grafis, perluasan bentuk program Radio Suara Surabaya dalam format digital adalah dokumentasi suara yang bisa dipanggil kembali sesuai tanggal dan jam yang diinginkan.

Dengan demikian, karakteristik radio konvensional yang bersifat selintas berubah menjadi abadi. Visualisasi materimateri program yang diudarakan melalui radio juga mengubah karakteristik radio yang invisible menjadi visible. Aspek 'Theatre of mind' di mana pendengar memiliki ruang untuk membayangkan dan bermain dengan imajinasi menjadi tereduksi.

\section{Proses Produksi Berita di Suara Surabaya Dot Net}

Berdasarkan tahapannya dalam sebuah ruang redaksi, konvergensi dibagibagi menurut tingkatannya. Level konvergensi $0 \%$ menunjukkan tidak ada kolaborasi antara dua media, sedangkan level 33\% menunjukkan awal kolaborasi dimulai. Schantin, (Trijayanto, 2015:30), menyatakan, level konvergensi $66 \%$ sudah ada pengalaman dengan kolaborasi dan level konvergensi $100 \%$ adalah operasi redaksi yang sudah terintegrasi penuh. Sedangkan menurut Pavlik, Jurnalisme online ialah jurnalisme yang mengintegrasikan tiga fitur komunikasi yang unik: kemampuan-kemampuan multimedia berdasarkan platform digital, kualitas-kualitas interaktif, komunikasikomunikasi online, dan fitur-fitur yang ditatanya.

Konsep interaktivitas (interactivity) dalam media digital merujuk kepada adanya kesempatan di mana teks dalam media baru mampu memberi kesempatan kepada pengguna (users) untuk langsung memberikan umpan balik dengan cara 'write back into the text'. Sedangkan konsep dispersal media baru lebih kepada proses produksi dan distribusi media menjadi decentralised dan mengandalkan keaktifan individu (highly individuated).

Di Suara Surabaya dot Net, interaktivitas dengan pengguna pada awalnya digerakkan oleh pendengar radio Suara Surabaya yang eksis dan loyal. Gambar 3 menunjukkan bagaimana alur produksi berita di http://suarasurabaya.net dan interaktivitas yang terjadi di level antar anggota redaksi dan di level antara redaksi (Admin, Supervisor, Manager) dengan pengguna (users) yang terdiri dari:

1. Laporan pendengar radio

2. Laporan reporter

3. Posting pengguna Facebook

4. Posting pengguna Twitter

Laporan reporter diposisikan sejajar dengan laporan pendengar radio (jurnalis warga). Untuk dapat diunggah ke laman portal http://suarasurabaya.net harus melalui tiga filter (Admin ODP, Supervisor dan Manajer). Sedangkan materi berita yang bersumber dari posting pengguna media sosial (facebook dan twitter), bisa langsung diakses melalui laman portal karena tersedia link kedua platform media sosial tersebut, dan tidak diperlukan penyaringan. Redaksi http://suarasurabaya.net sendiri dapat berinteraksi langsung (real time) dengan pengguna melalui akun resmi E-100 (Adelia, Diponegoro, Tembalang, \& Berita, 2019:173). 


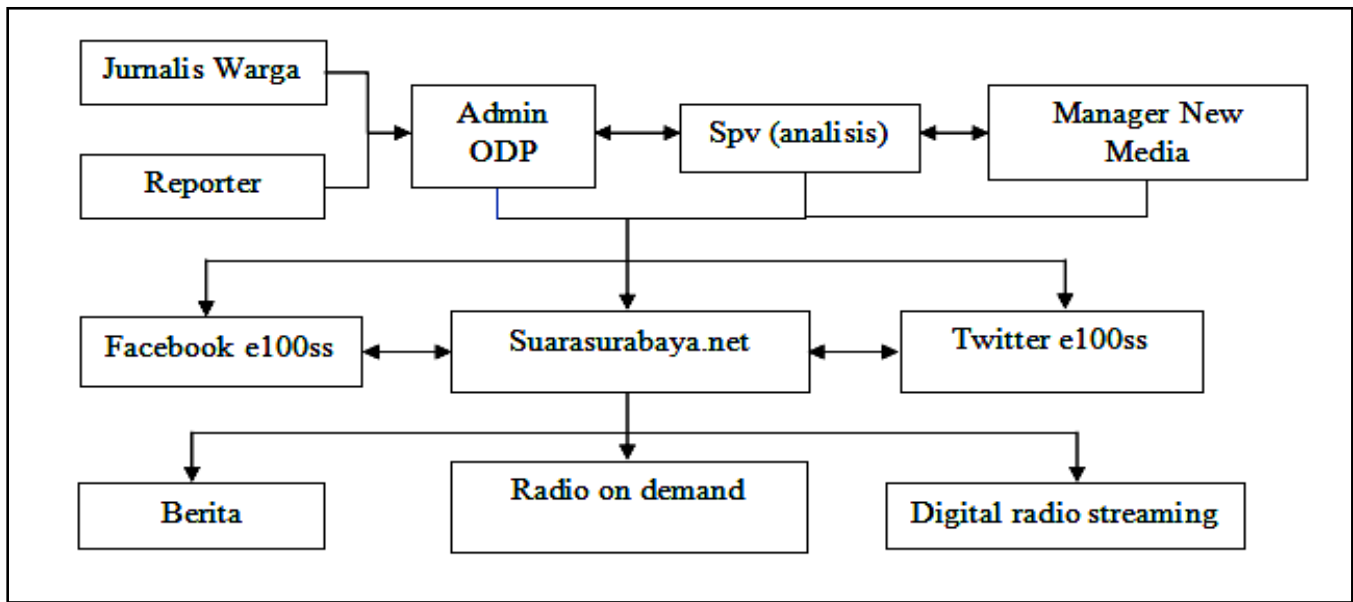

Gambar 3. Alur Produksi Berita dan konten lain di http://suarasurabaya.net Sumber: Wawancara Manajemen Suara Surabaya

\section{Pendekatan Engagement Pyramid Pada Proses Produksi Berita di Suara Surabaya Dot Net}

Model proses produksi berita seperti di atas berimplikasi pada struktur berita itu sendiri. Jika jurnalisme konvensional menggunakan pendekatan piramida terbalik, dengan mekanisme dan alternatif sumber berita yang dimiliki oleh suara surabaya dot net, pihak manajemen memutuskan untuk menggunakan pendekatan engagement pyramid (piramida keterlibatan).

Engagement Pyramid (Piramida

Keterlibatan) adalah konsep yang pertama kali dicetuskan oleh Charlene $\mathrm{Li}$ dalam bukunya Open Leadership (Baughan, 2019:61). Engagement pyramid menggambarkan bagaimana individu sebagai konsumen terlibat dalam proses penciptaan sebuah produk, image atau brand di era digital (Marta, Pricillia, Kasasih, \& Iskandar, 2015:24). Piramida ini tersusun dari lima tahapan keterlibatan, yaitu:

1. Melihat (watching), pada tahap ini keterlibatan individu masih rendah, bersifat pasif, misalnya hanya membaca, atau mengklik sebuah situs, menonton video.

2. Berbagi (sharing), pada tahap ini, keterlibatan individu mulai ada, namun belum sepenuhnya melibatkan diri. Misalnya dengan melakukan retweet, repost, regram.

3. Berkomentar (commenting), pada tahap ini individu meningkat keterlibatannya dengan berinteraksi secara aktif, misalnya dengan menelepon, mengomentari pada kolom reply di media sosial.

4. Memproduksi (producing), pada tahap ini individu sebagai konsumen secara sengaja dilibatkan oleh produsen dalam proses produksi. Misalnya, menjadi narasumber, dikutip pendapatnya.

5. Mengkurasi (currating), pada tahap ini individu sebagai konsumen memiliki kedudukan yang sama dengan produsen, turut menyeleksi dan mempertimbangkan apakah suatu produk layak, perlu atau sangat penting bagi publik. 


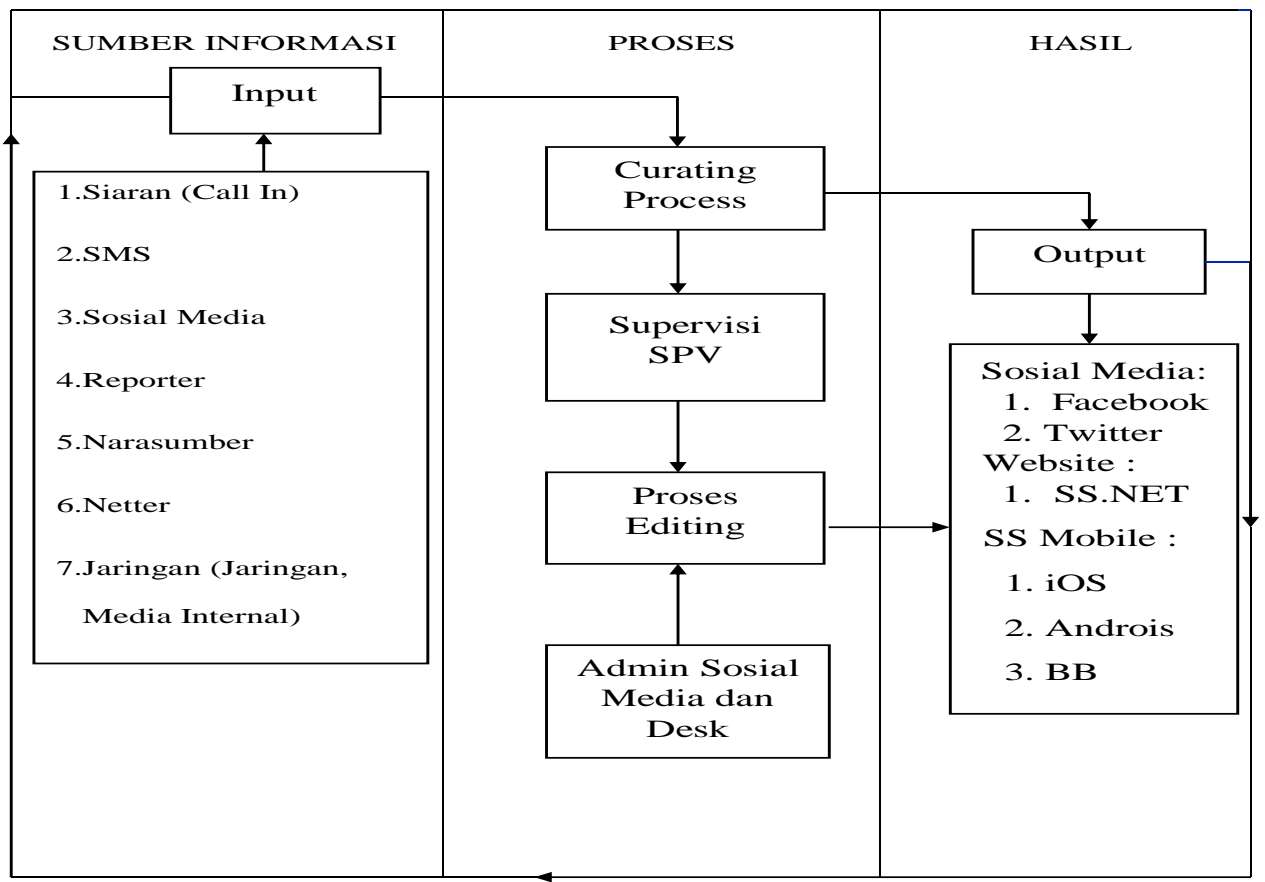

\section{Gambar 4. Pendekatan Engagement Pyramid dalam proses produksi konten pada portal berita http://suarasurabaya.net Sumber: wawancara Mananejemen http://suarasurabaya.net}

Secara faktual, berikut deskripsi bentuk-bentuk penerapan pendekatan Engagement Pyramid dalam proses produksi berita di http://suarasurabaya.net:

\section{Watching}

Pihak redaksi Suara Surabaya mengamati isi konten dari jurnalis warga yang telah diposting pada akun Facebook e100. Dari pengamatan tersebut admin sosial media mengumpulkan informasi serupa untuk mengambil keputusan, apakah berita tersebut cukup diberikan feedback dalam bentuk "LIKE", atau perlu untuk dikonfirmasi mengenai kebenaran dan kelengkapan data lewat komentar dan inbox atau perlu untuk diserahkan kepada SPV agar dianalisa lebih lanjut.

\section{Sharing}

Jurnalis warga sangat antusias untuk berbagi kiriman - kiriman di akun sosial media seperti Facebook dan Twitter. Jurnalis warga tersebut meng-upload atau mengirim foto, video, artikel kepada Facebook dan Twitter e100 Suara Surabaya. Mereka melakukan ini karena ingin berbagi informasi yang mereka miliki kepada sesama jurnalis warga atau netter. Di sini admin sosial media wajib memberikan sebuah penghargaan atau pengakuan atas berita yang jurnalis warga bagikan, pada akun sosial media e100. Penghargaan yang diberikan bisa berupa "LIKE", dirangkum dan kemudian diupload ulang atau dibagikan oleh pihak admin dengan disertakan nama jurnalis warga, atau retweet pada Twitter yaitu mengupload ulang atas nama akun @e100ss.

3. Commenting (Komentar)

Jurnalis warga kerap kali memberikan komentar pada kolom yang telah disediakan oleh pihak redaksi. Komentar-komentar tersebut bertujuan untuk melengkapi data yang diberikan oleh jurnalis warga lain, memberikan pendapat, melampirkan foto untuk memperjelas dan lain sebagainya.

Media sosial bersifat interaktif di mana setiap orang dapat berkomentar di bagian komentar yang sudah difalisitasi platform medsos. Sementara portal berita portal berita Suara Surabaya 
memiliki kolom khusus untuk komentar. Suara Surabaya memberikan kebebasan kepada jurnalis warga untuk berpartisipasi. Pihak redaksi online menggunakan kolom komentar untuk alat konfirmasi kepada pengirim informasi.

4. Producing

Pada tahap ini admin sosial media dan Supervisor sedang tahap melakukan konfirmasi dan klarifikasi untuk merangkum berita dari jurnalis warga. Setelah dikonfirmasi berita tersebut dirangkum dan di share. Apabila berita tersebut perlu untuk ditindak lanjuti secara mendalam, reporter Suara Surabaya turun ke lapangan dan hasilnya akan diunggah ke portal berita suarasurabaya.net. Format penulisan menjadi perhatian khusus oleh admin sosmed dan Supervisor, pada umumnya jaringan dengan Kepolisian, Jasa Marga, Jasa Raharja, dan semua pihak-pihak terkait sebagai narasumber.

Setelah melalui tahap verifikasi dan klarifikasi berita- berita tersebut diunggah ke sosial media Facebook e100 dan Twitter @e100ss, portal berita www.suarasurabaya.net, dan Aplikasi Suara Surabaya Mobile. Tampilan ouput, beranda sosial media facebook e100ss, twitter e100ss, suarasurabaya.net mengikuti format standar Facebook (maksimal 5000 kata) dan Twitter (maksimal 140 kata) dalam bentuk kronologis sesuai tanggal posting yang biasa disebut timeline (linimasa). Konten berita di media sosial e100ss yang sudah diklarifikasi penulisan berita adalah adanya $5 \mathrm{~W}+$ $1 \mathrm{H}$, perubahan dari bahasa tutur menjadi bahasa tulisan, dan lain sebagainya.

5. Curating

Kurator dalam Manajemen Pemberitaan Online adalah supervisor. SPV bertugas untuk mengedit berita dari reporter, memantau admin sosial media, memonitoring output dan komentar yang masuk, serta mempunyai wewenang untuk kebijakan tayang atau tidaknya berita tersebut. Laporan laporan jurnalis warga yang mengandung unsur urgent dan penting di analisa terlebih dahulu oleh Supervisor berdasarkan skema matrix laporan urgent, mengenai tayang tidaknya, reporter perlu mendalami laporan tersebut atau tidak. Suara Surabaya memiliki

oleh redaksi on air dan diliput secaramendalam oleh reporter kemudian diedit oleh Supervisor.

Hasil liputan dan klarifikasi yang telah melewati proses editing, tampil secara berbeda ketika diunggah di website suarasurabaya.net. Berita headline di http://suarasurabaya.net memiliki panjang antara 250-300 kata. Sedangkan flashnews di laman facebook e-100 hanya terdiri dari tak lebih 36-50 kata. Headline di http://suarasurabaya.net ditulis dengan mengadaptasi prinsip piramida terbalik dan $5 \mathrm{~W} 1 \mathrm{H}$, sedangkan di media sosial, identitas jurnalis warga dicantumkan sebagai elemen terpenting sebuah berita singkat
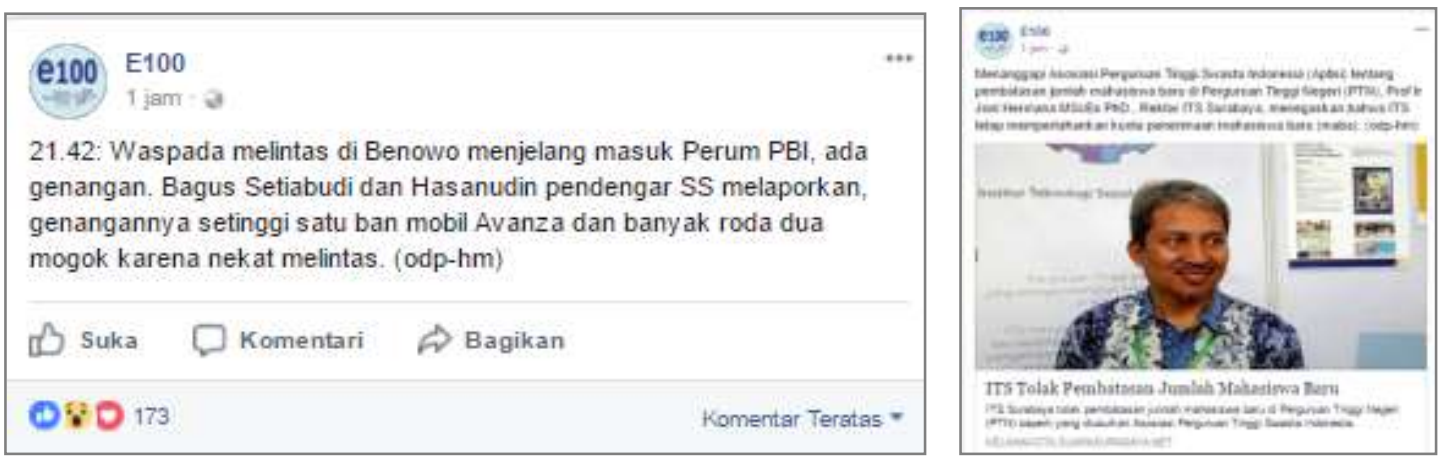

Gambar 5. Output Pendekatan Engagement Pyramid dalam bentuk flashnews di Facebook dan link Twitter e-100 Sumber: Facebook/e-00, twitter/e100 
Output lain yang dihasilkan oleh redaksi yang dicantumkan di media sosial adalah tautan (newslink). Prinsip penulisan newslink adalah tidak mencakup keseluruhan berita secara utuh, namun hanya intisarinya, tanpa judul berita. Sumber dikutip dalam bentuk pernyataan asli dan fotonya ditampilkan. Keterlibatan pengguna difasilitasi oleh platform media sosial Facebook, yaitu berkomentar pada kolom reply, memberikan opininya secara singkat yang diwakili dengan grafis like (suka), dislike (tidak suka), love (sangat suka), sad (sedih) dan angry (marah). Untuk berbagi, pengguna dapat memanfaatkan fasilitas klik share.

Berbeda dengan Facebook, newslink di platform micro blogging Twitter e-100 lebih singkat lagi dalam penggunaan kalimat pemantik, mengingat Twitter membatasi hanya 140 karakter sekali unggah. Pada gambar 5 dapat dilihat output jurnalisme daring Suara Surabaya dengan menggunakan pendekatan engagement pyramid ditampilkan dalam posting newslink di Twitter.

Keterlibatan pengguna difasilitasi oleh platform micro blogging Twitter, yaitu berkomentar pada kolom comment, memberikan opininya secara singkat yang diwakili dengan grafis love (suka), dan untuk berbagi, pengguna dapat memanfaatkan fasilitas klik retweet.

Engagement Pyramid pada dasarnya memberikan gagasan bahwa semakin terbuka dialog antara sebuah organisasi dalam melibatkan konsumennya atau pengguna produknya, makin besar pula peluang bagi individu-individu di luar organisasi tersebut untuk berperan sebagai pendukung yang loyal dan bersikap integratif terhadap organisasi, bahkan berperluang besar menjadi bagian dari pemasar (marketer).

Keterlibatan menumbuhkan dukungan dan tanggung jawab. Dengan terlibat sebagai supplier berita bagi suarasurabaya.net, baik melalui telepon radio, atau posting media sosial, individu merasa memiliki kedekatan bahkan sense of belonging terhadap http://suarasurabaya.net. Mereka merasa perlu meluruskan ketika ada berita yang tidak sesuai dengan kenyataan, karena nama mereka tercantum sebagai sumber berita. Mereka merasa perlu untuk menulis posting reply secara bertanggung jawab, karena platform media sosial yang mereka gunakan (Facebook maupun Twitter) secara otomatis menampilkan nama atau nama akun mereka sebagai sumber. Dengan demikian, penerapan engagement pyramid dalam jurnalisme daring, memungkinkan proses yang sehat dalam produksi pemberitaan dan hasil yang lebih bertanggung jawab, karena verifikasi turut dilakukan oleh pengguna, sehingga click bait atau bahkan hoax dapat dilawan oleh pengguna sendiri.

Dalam proses standar jurnalistik, pihak pengelola, dalam hal ini manajemen redaksi Suara Surabaya dot Net tetap menerapkan pola verfikasi, menguji validitas informasi yang bersumber dari jurnalis warga. Dilihat dari cara kerja newsroom atau redaksi http://suarasurabaya.net yang terintegrasi dengan media konvensional radio Suara Surabaya, dapat dikatakan bahwa tingkatannya sudah mencapai level konvergensi $100 \%$, karena operasi redaksi sudah terintegrasi penuh.

Lima tahapan dalam engagement pyramid diterapkan oleh suarasurabaya.net, sehingga menghasilkan konten yang variatif pada laman portal beritanya. Kontribusi terbesar didapat dari Radio Suara Surabaya yang memang menjadi induk dari media ini. Dengan mempertimbangkan kecenderungan peningkatan pengguna mobile gadget dan aksesibilitas pengguna internet, besar peluang laman portal berita http://suarasurabaya.net untuk lebih banyak diakses oleh pengguna ketimbang media konvensional pendahulunya, Radio Suara Surabaya.

\section{Implikasi Pendekatan Engagement Pyramid Pada Penulisan Naskah Berita di Suara Surabaya Dot Net}

Pada konteks yang paling praktis, yaitu bagaimana pendekatan engagement pyramid diterapkan dalam penulisan naskah berita, berikut contoh anatomi naskah berita yang diunggah di portal berita http://suarasurabaya.net, dengan melihat kesesuaiannya dengan struktur penulisan berita berdasarkan prinsip Piramida Terbalik. 

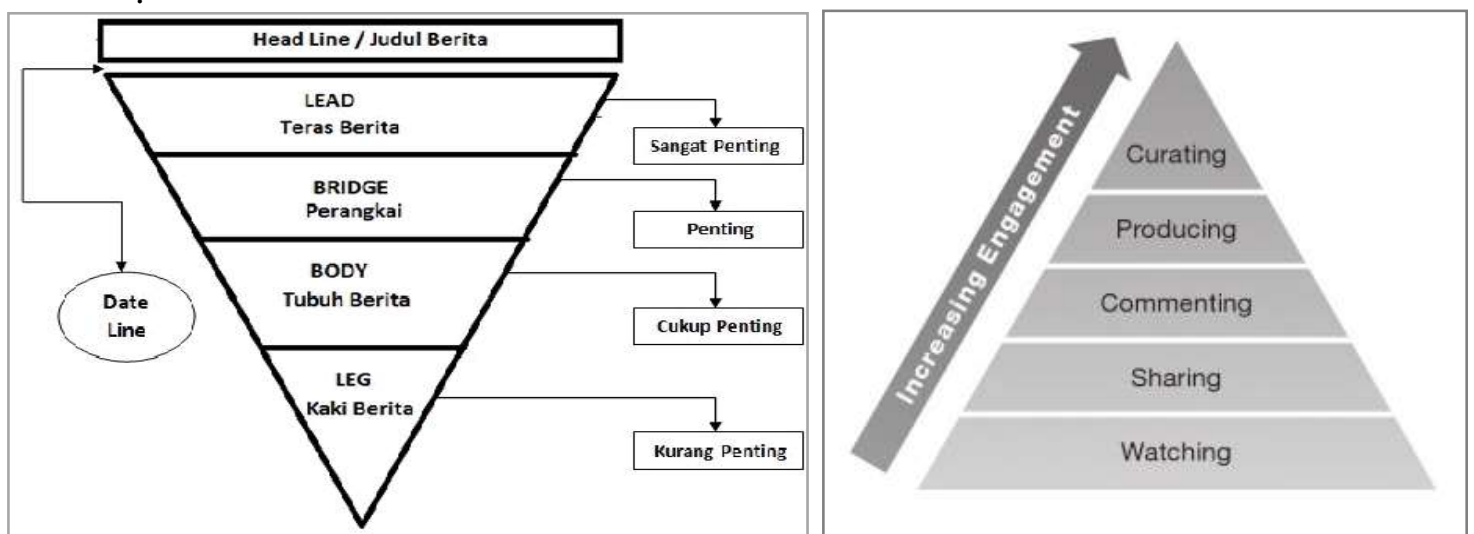

Gambar 6. Perbandingan Struktur Piramida Terbalik dengan Struktur Engagement Pyramid

Sumber: (Insani, Hidayat, \& Zulfan, 2019:53)

\begin{abstract}
Panjang naskah berita yang diunggah di portal berita http://suarasurabaya.net rata-rata 11 paragraf, masing-masing paragraf terdiri dari rata-rata 22 kata, dan setiap paragraf dipisahkan dengan paragraf lainnya dengan
\end{abstract}

menggunakan spasi. Dari contoh berita berjudul "KPK Ungkap Jumlah Uang yang Disita dari Ruang Kerja Menteri Agama" di bawah ini dapat dilihat bahwa unsur-unsur dalam prinsip piramida terbalik terpenuhi, namun dengan proporsi yang spesifik.

\section{Tabel 1. Penerapan Pendekatan Engagement Pyramid dalam struktur berita di portal} berita http://suarasurabaya.net.

\begin{tabular}{|c|}
\hline KPK Ungkap Jumlah Uang yang Disita dari Ruang Kerja Menteri Agama \\
\hline 2. Date line \\
\hline Laporan Farid Kusuma | Selasa, 19 Maret 2019|20:55 WIB \\
\hline 3. Lead (Teras Berita) \\
\hline $\begin{array}{l}\text { suarasurabaya.net - Tim Komisi Pemberantasan Korupsi (KPK) sudah menghitung jumlah } \\
\text { uang yang kemarin, Senin (18/3/2019), disita dari Ruang Kerja Lukman Hakim Saifuddin } \\
\text { Menteri Agama. }\end{array}$ \\
\hline 4. Bridge (Perangkai) \\
\hline $\begin{array}{l}\text { Febri Diansyah Juru Bicara KPK mengatakan, dari proses penggeledahan, ditemukan mata } \\
\text { uang rupiah sebanyak Rp180 juta, dan } 30 \text { ribu Dollar AS atau setara Rp420 juta (kurs } \\
\text { Rp14 ribu). }\end{array}$ \\
\hline $\begin{array}{l}\text { Jadi, kalau dijumlahkan, total uang yang jadi barang bukti dugaan suap jual beli jabatan di } \\
\text { Kementerian Agama, sebanyak Rp600 juta. }\end{array}$ \\
\hline 5. Body (Tubuh Berita) \\
\hline $\begin{array}{l}\text { "Sesudah dihitung, jumlah uang yang ditemukan di Ruang Kerja Menteri Agama sebanyak } \\
\text { Rp180 juta, dan } 30 \text { ribu Dollar AS," ujarnya di Kantor KPK, Jakarta Selatan, Selasa } \\
(19 / 3 / 2019) \text {. }\end{array}$ \\
\hline $\begin{array}{l}\text { KPK, lanjut Febri, masih mengusut dari mana asal-usul uang yang tersimpan di laci meja } \\
\text { kerja Menteri Agama, dan kaitannya dengan kasus dugaan korupsi yang sementara ini } \\
\text { menjerat oknum pejabat Kemenag serta politisi. }\end{array}$ \\
\hline
\end{tabular}




\section{Leg (Kaki Berita)}

Selain uang, KPK juga menyita sejumlah dokumen dari Ruang Kerja Menteri, Sekretaris Jenderal dan Kepala Biro Kepegawaian Kementerian Agama.

Lalu, dari Kantor DPP Partai Persatuan Pembangunan (PPP), kawasan Menteng, Jakarta Pusat, penyidik mengambil dokumen berupa rekening koran.

Sedangkan dari rumah tinggal Romahurmuziy bekas Ketua Umum PPP di kawasan Condet, Jakarta Timur, Tim Komisi Antirasuah menyita sebuah laptop.

Seperti diketahui, Sabtu (16/3/2019), KPK menetapkan Romahurmuziy yang akrab disapa Romi sebagai tersangka penerima suap.

Selain Romi, KPK juga menetapkan Muhammad Muafaq Wirahadi Kepala Kantor Kementerian Agama Kabupaten Gresik, dan Haris Hasanuddin Kepala Kantor Wilayah Kementerian Agama Provinsi Jawa Timur sebagai tersangka pemberi suap.

KPK menduga Romahurmuziy menerima suap Rp300 juta, untuk mengatur hasil seleksi dua jabatan tinggi di Kementerian Agama tersebut. (rid/iss/ipg)

Sumber: https://kelanakota.suarasurabaya.net/news/2019/218340-KPK-Ungkap-JumlahUang-yang-Disita-dari-Ruang-Kerja-Menteri-Agama, diolah peneliti.

Secara anatomis, struktur penulisan berita pada portal http://suarasurabaya.net tetap mengikuti prinsip piramida terbalik, dengan menempatkan bagian yang paling penting pada bagian awal tulisan. Yang nampak berbeda adalah pemilihan kata atau penggunaan bahasanya. Untuk berita yang sama, sejumlah portal berita menggunakan judul yang mendekati click bait, contoh:

1. Usai Geledah Ruang Kerja Menteri Agama, Penyidik KPK Bawa Dua Koper (Jawa Pos, 18 Maret 2019)
2. KPK Temukan Uang Ratusan Juta di Ruang Menteri Agama Lukman Hakim (tempo.co, 18 Maret 2019)

3. KPK Sita Uang di Ruang Menteri Agama, Mahfud MD Pernah Sebut Lukman Saifuddin Bersih Tapi ... (tribunnews.com)

Jika struktur ini dilihat berdasarkan pendekatan Engagement Pyramid, maka struktur penulisan pada berita yang diunggah di http://suarassurabaya.net adalah sebagai berikut:

Tabel 2. Penerapan Pendekatan Engagement Pyramid dalam struktur berita di portal berita http://suarasurabaya.net.

\section{Tahap Melihat (watching)}

\section{Judul}

KPK Ungkap Jumlah Uang yang Disita dari Ruang Kerja Menteri Agama

\section{Date line}

Laporan Farid Kusuma | Selasa, 19 Maret 2019 | 20:55 WIB

Tahap Berbagi (sharing)

Lead (Teras Berita)

suarasurabaya.net - Tim Komisi Pemberantasan Korupsi (KPK) sudah menghitung jumlah uang yang kemarin, Senin (18/3/2019), disita dari Ruang Kerja Lukman Hakim Saifuddin Menteri Agama. 


\section{Bridge (Perangkai)}

Febri Diansyah Juru Bicara KPK mengatakan, dari proses penggeledahan, ditemukan mata uang rupiah sebanyak Rp180 juta, dan 30 ribu Dollar AS atau setara Rp420 juta (kurs Rp14 ribu).

Jadi, kalau dijumlahkan, total uang yang jadi barang bukti dugaan suap jual beli jabatan di Kementerian Agama, sebanyak Rp600 juta.

\section{Body (Tubuh Berita)}

"Sesudah dihitung, jumlah uang yang ditemukan di Ruang Kerja Menteri Agama sebanyak Rp180 juta, dan 30 ribu Dollar AS," ujarnya di Kantor KPK, Jakarta Selatan, Selasa $(19 / 3 / 2019)$.

KPK, lanjut Febri, masih mengusut dari mana asal-usul uang yang tersimpan di laci meja kerja Menteri Agama, dan kaitannya dengan kasus dugaan korupsi yang sementara ini menjerat oknum pejabat Kemenag serta politisi.

\section{Leg (Kaki Berita)}

Selain uang, KPK juga menyita sejumlah dokumen dari Ruang Kerja Menteri, Sekretaris Jenderal dan Kepala Biro Kepegawaian Kementerian Agama.

Lalu, dari Kantor DPP Partai Persatuan Pembangunan (PPP), kawasan Menteng, Jakarta Pusat, penyidik mengambil dokumen berupa rekening koran.

Sedangkan dari rumah tinggal Romahurmuziy bekas Ketua Umum PPP di kawasan Condet, Jakarta Timur, Tim Komisi Antirasuah menyita sebuah laptop.

Seperti diketahui, Sabtu (16/3/2019), KPK menetapkan Romahurmuziy yang akrab disapa Romi sebagai tersangka penerima suap.

Selain Romi, KPK juga menetapkan Muhammad Muafaq Wirahadi Kepala Kantor Kementerian Agama Kabupaten Gresik, dan Haris Hasanuddin Kepala Kantor Wilayah Kementerian Agama Provinsi Jawa Timur sebagai tersangka pemberi suap.

KPK menduga Romahurmuziy menerima suap Rp300 juta, untuk mengatur hasil seleksi dua jabatan tinggi di Kementerian Agama tersebut. (rid/iss/ipg)

Sumber: https://kelanakota.suarasurabaya.net/news/2019/218340-KPK-Ungkap-JumlahUang-yang-Disita-dari-Ruang-Kerja-Menteri-Agama, diolah peneliti.

Dalam struktur penulisan berita, pendekatan Engagement Pyramid hanya diaplikasikan sampai pada tahap watching (melihat). Pada tahap Melihat, keterlibatan individu rendah, bersifat pasif, reaksi pengguna sebatas membaca. Dengan demikian, isi berita sepenuhnya menjadi wewenang redaksi, dan reaksi yang diharapkan adalah mengkonsumsi berita secara utuh. Pola ini berbeda berita yang menggunakan struktur penulisan piramida terbalik, tetapi menggunakan judul click bait yang cenderung menstimuli reaksi cepat untuk pembaca menduga isi berita atau memiliki preferensi tertentu terhadap isi berita.

Tahap selanjutnya dalam engagement pyramid yang meliputi berbagi (sharing), berkomentar (commenting), berbagi (sharing), memproduksi (producing), dan mengkurasi (currating), dilakukan oleh http://suarasurabaya.net secara terpisah, tidak pada anatomi berita, tetap di luar tubuh berita. Pada tahap sharing, pengguna atau pembaca sudah melalui terlibat dengan melakukan retweet, repost. Portal suarasurabaya.net memfasilitasi pengguna untuk berbagi 
melalui dua platform media sosial, yaitu Facebook dan Twitter, serta satu platform chatroom yaitu Whatsapp. Tahap Berkomentar (commenting), di mana individu meningkat keterlibatannya dengan berinteraksi secara aktif, yaitu mengomentari berita, difasilitasi oleh http://suarasurabaya.net dengan menyediakan kolom reply yang dilengkapi dengan field data yang wajib diisi, terdiri dari nama, kota, email, telepon, komentar terhadap berita dan kode verifikasi berupa angka dan huruf acak. Disediakan juga pilihan apakah komentar tersebut akan diunggah atau tidak, dengan memberi alternatif tombol 'kirim' dan 'batal'. Di bagian paling akhir dari fasilitas yang disediakan http://suarasurabaya.net bagi pembaca untuk terlibat dengan melakukan sharing, tercantum peringatan:

"Redaksi menerima komentar terkait artikel yang ditayangkan. Isi komentar menjadi tanggung jawab pengirim. Redaksi berhak untuk tidak menampilkan komentar jika dianggap tidak etis, kasar, berisi fitnah, atau berbau SARA."

Mekanisme ini mengarahkan agar pengguna mengerti bahwa komentar yang dikirim merupakan tanggung jawab pribadi, bukan tanggung jawab redaksi http://suarasurabaya.net.

Dengan demikian, berdasarkan anatomi penulisan naskahnya, tahap memproduksi (producing), dan mengkurasi (currating), tidak dimasukkan dalam struktur berita. Untuk kategori berita headline, redaksi http://suarasurabaya.net tidak melibatkan individu dalam proses produksi berita, dalam konteks pengutipan. narasumber, suarasurabaya.net hanya mengutip sumber resmi dan bukan berangkat dari komentar pengguna media sosial yang dicuplik dan dijadikan bagian dari berita.

Dengan mekanisme tersebut, keterlibatan pengguna pada tahap berikutnya, yaitu mengkurasi (currating) justru lebih terjaga, di mana pada tahap ini individu sebagai konsumen memiliki kedudukan yang sama dengan produsen, turut menyeleksi dan mempertimbangkan apakah suatu produk layak, perlu atau sangat penting bagi publik. Pembaca tidak serta merta berkomentar tanpa diseleksi, tapi harus melalui proses dimana pembaca dan redaksi berinteraksi di ruang redaksi virtual sehingga keputusan terakhir kelayakan muat komentar tersebut, tetap berada di tangan redaksi.

Mekanisme ini secara konkrit memberi ruang yang sangat luas bagi penerapan standar etis konstitusional di media baru. Etika bermedia menurut (Fensi, 2018:133-209), pertama, kepatuhan kepada hukum media (sosial) untuk menghindari perilaku fitnah. Kedua, menjunjung tinggi akurasi dalam penyampaian pesan. Ketiga, memperhitungkan hak istimewa (privilege) yang melekat pada seseorang. Ada absolute privilege, qualified privilege, dan person of interest. Etika kritik dalam tiga hak ini harus bersifat adil, dalam pengertian kritik yang tidak diarahkan untuk menyerang unsur-unsur pribadi pada mereka yang memiliki ketiga hak istimewa ini. Keempat, menghindari pengungkapan secara publik urusan privat orang lain. Kelima, menghindari penyampaian pesan yang bersifat membohongi, atau menipu khalayak. Keenam, mempertimbangkan secara etis sensitivitas keragaman budaya (multikulturalisme).

\section{Pendekatan Engagement Pyramid sebagai Standar Jurnalisme Daring}

Digitalisasi telah menjadi salah satu pendorong utama perubahan sifat dan karakteristik jurnalisme, karena digitalisasi memengaruhi nilai berita, etika profesional, arus kerja, kondisi kerja, dan manajemen ruang redaksi. Sisi positifnya, digitalisasi meningkatkan akses warga terhadap informasi dan saluran diseminasi, tetapi pada saat yang sama juga berpotensi memunculkan sejumlah praktik non-etis, yang paling umum sekaligus mengkhawatirkan adalah plagiarisme, duplikasi dan kurangnya verifikasi. Akibatnya, peluang terjadi disinformasi dan bahkan penyebaran hoax semakin besar. 
Digitalisasi memberikan keuntungan besar bagi masyarakat berupa tersedianya ruang tumbuh untuk kebebasan berekspresi bagi kelompok minoritas, khususnya etnis dan minoritas seksual, kelompok-kelompok yang terpinggirkan memiliki kesempatan untuk membuat suara mereka didengar (Marselis, 2011:90). Pada praktiknya, warga memang ada yang benarbenar terlibat dalam proses pelaporan, ikut melakukan penelusuran informasi, bahkan sebelum memposting tulisan mereka di internet.

Dalam konteks Suara Surabaya, keterlibatan khalayak secara intens sebenarnya bukan dimulai sejak mereka menyelenggarakan media konvergen berupa portal berita dengan berbagai fitur media, termasuk radio on demand, media sosial dan interaktivitas di dalamnya. Justru, sejak awal didirikan, radio ini menerapkan perencanaan program (programming) yang berbasis keterlibatan, di mana pendengar bisa memberikan laporan langsung, melengkapi laporan pendengar sebelumnya, mengkritisi pendapat pendengar lain, bahkan bekerjasama dengan pendengar lain untuk menangkap pencuri mobil dengan cara bergantian meng-update laporan kepada penyiar. Kultur terlibat (engage) dengan isu lokal ini merupakan modal yang sangat penting ketika era digitalisasi tiba. Pengelola media, termasuk redaksi, reporter, editor telah terbiasa dengan perilaku jurnalisme warga sehingga bukan hal yang sulit bagi mereka.

Pendekatan Engagement Pyramid yang relatif luwes, karena memberi ruang kepada semua pihak yang terlibat dalam produksi berita untuk saling menjalankan perannya sebagai konsumen sekaligus produser berita, dapat diterapkan sebagai standar bagi jurnalisme daring. Sebagaimana diketahui, sejak kemunculan internet, media konvensional termasuk radio secara pelahan namun pasti semakin ditinggalkan. Yang paling memprihatinkan sebenarnya justru pesimisme dari kalangan meda itu sendiri yang mengkhawatirkan masa depan media mereka, tak terkecuali media radio siaran, tanpa melakukan tindakan yang cukup berarti untuk menyelamatkan diri. Penyesuaian standar jurnalistik seharusnya menjadi agenda utama dalam upaya mencegah media konvensional dari ditinggalkan khalayaknya.

Pendekatan Engagement Pyramid bisa saja diadopsi sebagai standar baru dalam jurnalisme daring yang sekaligus mengakomodasi jurnalisme penyiaran yang dalam pengemasannya telah beradaptasi dengan karakteristik media konvergen. Dengan demikian, para pelaku produksi konten media daring, termasuk di dalamnya pekerja media (jurnalis, reporter, editor, penyiar, penulis) serta warga sebagai prosumer konten media, sama-sama memiliki acuan etis dalam menghasilkan informasi yang mereka butuhkan dan mereka ingin bagikan. Pendekatan Engagement Pyramid dapat diibaratkan sebagai ban pelampung (lifebuoy) yang menjaga keterikatan emosional antara media dengan khalayaknya tetap hidup dan manusiawi.

Jurnalisme daring akan sangat membutuhkan keterlibatan warga. Adapun jurnalisme warga (citizen journalism) sendiri, pada dasarnya bukan sekedar warga yang menelepon, memberi laporan, mengunggah video yang kemudian digunakan oleh media sebagai pelengkap dalam bentuk footage, kutipan maupun soundbite. Jurnalisme warga adalah segala bentuk karya jurnalistik yang diproduksi oleh warga diterbitkan sebagai berita transparan yang mengikuti nilai-nilai jurnalistik seperti: kejujuran, akurasi, keseimbangan dan objektifitas. Pendekatan yang digunakan dalam citizen journalism tidak formal tetapi bukan personal, bersandarkan pada perspektif mereka sendiri (subyektif). Karena itu, walaupun penulis merupakan warga masyarakat biasa yang mungkin tidak memiliki keterampilan jurnalistik, tetapi tulisan yang disebarluaskan harus tetap melalui proses penyaringan dan editing (Alamiyah, 2015:30).

Di sisi lain, konvergensi teknologi telah memberi keuntungan secara finansial dengan memberdayakan lembaga penyiaran untuk menjadi penyedia berita online, namun sekaligus berpeluang mendistorsi pasar berita online non konvergen, dan 
sangat mungkin membahayakan pasar mereka, dengan kata lain mempertajam persaingan antara sesama media daring. Pendekatan Engagement Pyramid dapat menjadi sarana dasar untuk menentukan ceruk pasar. Artinya, pengelola media dapat menentukan secara lebih spesifik segmentasi yang akan mereka bidik dan bagaimana menjalin keteribatan yang lebh intens dengan mereka.

Dalam konteks Suara Surabaya, hal tersebut telah dilakukan dengan membagi segmen acara yang memiliki keterlibatan tinggi dengan segmen khalayak tertentu. Program-program tertentu dirancang dengan pendekatan yang sesuai dengan umur khalayaknya, sehingga pilihan gaya, bahasa dan angle pun berbeda. Misalnya, program 'Titik Nol' untuk segmen pendengar usia di atas 40 tahun disajikan dengan gaya yang lebih serius, berbeda dengan program 'Muda Tapi Luar Biasa yang ditujukan untuk segmen pendengar usia 25 tahun. Pendekatan Engagement Pyramid memudahkan para jurnalis, reporter dan editor untuk mengeksekusi karya jurnalistik mereka.

\section{SIMPULAN}

Pendekatan engagement pyramid yang merupakan respon terhadap semakin kompleksnya relasi antara produsen di era digital dan konsumen, menawarkan jalan tengah agar keberlanjutan sebuah organisasi, produk maupun brand dapat terjaga, melalui satu konsep kunci yaitu keterlibatan. Dalam konteks konvergensi media radio dengan media online, pendekatan engagement pyramid yang diterapkan oleh http://suarasurabaya.net berimplikasi pada variasi struktur penulisan jurnalistik pada tiap platform. Variasi ini diperlukan karena masing-masing platform media baru menyediakan fasilitas sekaligus keterbatasan yang memengaruhi cara pengguna mengkonsumsi berita. Pengguna akan membaca website untuk berita yang lebih lengkap tanpa keterlibatan penuh. Namun jika mereka menginginkan berita sekaligus terlibat lebih jauh dalam berita tersebut, pengguna akan mengakses media sosial dan media konvensional radio Suara
Surabaya yang menyediakan kesempatan untuk terlibat pada proses sharing, commenting, producing, dan currating.

Dalam implementasinya, pendekatan engagement pyramid tidak secara keseluruhan dimasukkan dalam struktur naskah berita. Redaksi http://suarasurabaya.net tetap menggunakan prinsip penulisan jurnalistik piramida terbalik, sedangkan penerapan engagement pyramid hanya sampai pada tahap melihat (watching). Keterlibatan individu sebagai pembaca pada tahap sharing, commenting, producing, dan currating tidak dimasukkan dalam struktur naskah, sehingga akurasi dan independensi redaksi tetap terjaga.

Pendekatan Engagement Pyramid dapat dijadikan sebagai standar baru dalam jurnalisme daring. Sebagaimana telah dilakukan oleh radio Suara Surabaya dan media konvergen-nya http:// suarasurabaya.net. Engagement Pyramid memudahkan para jurnalis, reporter dan editor untuk mengeksekusi karya jurnalistik mereka.

\section{DAFTAR PUSTAKA}

Adelia, O., Diponegoro, U., Tembalang, K. U., \& Berita, P. (2019). PENGGUNAAN MEDIA SOSIAL OLEH WARTAWAN JAWA POS. Interaksi Online, 7(3), 171-182. Retrieved from https://ejournal3.undip.ac.id/index.php /interaksi-online/article/view/24156

Alamiyah, S. S. (2015). Peluang Dan Tantangan Citizen Journalism Di Indonesia. Jurnal Ilmu Komunikasi, $7(2), 27-38$.

Alatas, S., \& Sutanto, V. (2019). Cyberfeminisme and Female Empowerment through New Media. Jurnal Komunikasi Pembangunan, 17(2), 165-176. https://doi.org/https://doi.org/10.2924 4/jurnalkmp.17.2.165-176

Asy'ari, N. A. S., \& Luthfi, M. (2018). ANALISIS PENERAPAN KONVERGENSI MEDIA PADA USAHA PENYIARAN RADIO DI PONOROGO. Perspektif Komunikasi, 1(2). Retrieved from 
https://jurnal.umj.ac.id/index.php/pers pektif/article/view/3892

Baughan, C. C. (2019). Using Coaching and Performance Feedback to Increase Head Start Teachers, Use of Teaching Pyramid Model Practices. Dialog, 22(1), 57-76. Retrieved from https://journals.uncc.edu/dialog/article /view/774

Fensi, F. (2018). FENOMENA HOAX: Tantangan terhadap Idealisme Media \& Etika Bermedia. Bricolage: Jurnal Magister Ilmu Komunikasi, 4(2), 116.

https://doi.org/http://dx.doi.org/10.308 13/bricolage

Hamna, D. M. (2018). KONVERGENSI MEDIA TERHADAP KINERJA JURNALIS (STUDI KASUS: FAJAR TV DAN FAJAR FM). Jurnal Dakwah Tabligh, 19(1), 58-83. https://doi.org/10.24252/jdt.v19i1.591 1

Insani, C. N., Hidayat, D. R., \& Zulfan, I. (2019). Pemanfaatan Insta Story Dalam Aktivitas Jurnalistik Oleh Majalah Gadis. Jurnal Kajian Jurnalisme, 3(1), 40-56. https://doi.org/10.24198/jkj.v3i1.2245 3

Khadziq, K. (2016). KONVERGENSI MEDIA SURAT KABAR LOKAL (Studi Deskriptif Pemanfaatan Internet Pada Koran Tribun Jogja dalam Membangun Industri Media Cetak Lokal). Profetik: Jurnal Komunikasi, 10(1), 5-20. https://doi.org/10.14421/pjk.v9i1.1187

Marselis, R. (2011). Digitizing migration heritage: A case study of a minority museum. MedieKultur: Journal of Media and Communication Research, 27(50), 84-99. https://doi.org/10.7146/mediekultur.v 27i50.3325

Marta, R. F., Pricillia, P., Kasasih, M. F., \& Iskandar, M. C. E. (2015). ANALISIS KOMUNIKASI PEMASARAN MELALUI STRATEGI BRAND ACTIVATION POND'S UNTUK MERAIH TOP BRAND AWARD 2013. Jurnal Ilmiah Komunikasi Makna, 6(1), 22-30. Retrieved from http://jurnal.unissula.ac.id/index.php/ makna/article/view/2778/2034

Nugroho, Y., Putri, D. A., \& Laksmi, S. (2012). Memetakan Lansekap Industri Media Kontemporer di Indonesia (Vol. 2). Retrieved from https://s3.amazonaws.com/academia.e du.documents/31581151/PemetaanIndustri-

Media_FINAL_IND_052013.pdf?resp onse-content-disposition=inline $\% 3 \mathrm{~B}$ filename\%3DMemetakan_Lansekap_I ndustri_Media_Kontem.pdf\&X-AmzAlgorithm=AWS4-HMAC-

SHA256\&X-Amz-

Credential=AKIAIWOWYYGZ2Y53

UL3A\%2F20191029\%2Fus-east-

1\%2Fs3\%2Faws4_request\&X-Amz-

Date $=20191029$ T072330Z \&X-Amz-

Expires $=3600 \& X-A m z-$

SignedHeaders $=$ host $\& X-A m z-$

Signature $=\mathrm{dc} 0157 \mathrm{f} 1 \mathrm{ff} 0 \mathrm{a} 37 \mathrm{c} 85 \mathrm{a} 95211$

a7f683c94ee021a55510974b34c44223 45d4849ee

Permadi, A. (2019). PERILAKU JURNALISTIK PROFETIK MEDIA SIBER DALAM MEWUJUDKAN MASYARAKAT MADANI (STUDI FENOMENOLOGI DI KALANGAN WARAWAN MUSLIM PADA MEDIA SIBER DI KOTA BANDUNG). Syntax Idea, 1(4), 2332. Retrieved from http://jurnal.syntax-

idea.co.id/index.php/syntaxidea/article/download/32/49

Prilani, P. (2017). Content Aggregator: Problem Etis Jurnalisme Online Di Indonesia. Jurnal Nomosleca, 3(1), 515-525.

https://doi.org/10.26905/nomosleca.v3 i1.1483

Sediyaningsih, S. (2018). KONVERGENSI MEDIA DI ERA DIGITAL ( EKSPLOITASI MEDIA KOMUNIKASI DALAM PROSES BELAJAR MENGAJAR DI ERA DIGITAL ). Jurnal Pendidikan Terbuka Dan Jarak Jauh, 19(1), 5257.

https://doi.org/https://doi.org/10.3383 0/ptjj.v19i1.752.2018

Trijayanto, D. (2015). Implikasi 
Konvergensi Media Terhadap Industri "Premateur Industri Penyiaran Televisi Digital pada Teknologi Layanan Mobile Television di Indonesia." PROMEDIA, I(1), 19-42. Retrieved from http://journal.uta45jakarta.ac.id/index. php/kom/article/download/97/76

Trinoviana, A. (2017). Strategi Konvergensi Radio Sebagai Upaya Perluasan Pasar Audience dan Iklan (Studi Kasus Pada Swaragama Fm (101.7 Fm), Geronimo Fm (106.1 Fm), Dan Prambors Radio (102.2 FM/95.8 FM)). Jurnal Komunikasi, 12(1), 35-50. https://doi.org/10.20885/komunikasi.v ol12.iss1.art3

Winarni, N., \& Lestari, R. D. (2019). Sumber Berita Netizen dalam Perspektif Etika Jurnalistik (Studi Kasus pada Media Online Jogja.tribunnews.com). Journal Pekommas, 4(1), 85-96. https://doi.org/10.30818/jpkm.2019.20 40109 